\title{
Nasal-Swab Testing Misses Patients with Low SARS-CoV-2 Viral Loads
}

\author{
Cody Callahan ${ }^{a}$, Rose A. Lee $^{b, c, d}$, Ghee Rye Lee $^{\mathrm{e}}$, Kate Zulauf,, \\ James E. Kirby, ${ }^{\mathrm{b}, \mathrm{d}}$ and Ramy Arnaout ${ }^{\mathrm{b}, \mathrm{d}, \mathrm{f}, \#}$
}

aDepartment of Radiology, Beth Israel Deaconess Medical Center, Boston, MA, USA 02215

${ }^{\mathrm{b}}$ Department of Pathology, Beth Israel Deaconess Medical Center, Boston, MA, USA

'Division of Infectious Diseases, Department of Medicine, Beth Israel Deaconess Medical

Center, Boston, MA, USA

${ }^{\mathrm{d} H}$ arvard Medical School, Boston, MA, USA

eDepartment of Surgery, Beth Israel Deaconess Medical Center, Boston, MA, USA 02215

fDivision of Clinical Informatics, Department of Medicine, Beth Israel Deaconess Medical Center, Boston, MA USA 02215

${ }^{\#}$ To whom correspondence should be addressed at

Ramy Arnaout, MD, DPhil

Beth Israel Deaconess Medical Center

330 Brookline Avenue-YA309

Boston, MA 02215

rarnaout@bidmc.harvard.edu

617-667-3648 
medRxiv preprint doi: https://doi.org/10.1101/2020.06.12.20128736; this version posted June 14, 2020. The copyright holder for this preprint (which was not certified by peer review) is the author/funder, who has granted medRxiv a license to display the preprint in perpetuity.

It is made available under a CC-BY-NC-ND 4.0 International license .

\section{Abstract}

The urgent need for large-scale diagnostic testing for SARS-CoV-2 has prompted pursuit of sample-collection methods of sufficient sensitivity to replace sampling of the nasopharynx (NP). Among these alternatives is collection of nasal-swab samples, which can be performed by the patient, avoiding the need for healthcare personnel and personal protective equipment. Previous studies have reached opposing conclusions regarding whether nasal sampling is concordant or discordant with NP. To resolve this disagreement, we compared nasal and NP specimens collected by healthcare workers in a cohort consisting of individuals clinically suspected of COVID-19 and outpatients known to be SARS-CoV-2 RT-PCR positive undergoing follow-up. We investigated three different transport conditions, including traditional viral transport media (VTM) and dry swabs, for each of two different nasal-swab collection protocols on a total of 308 study participants, and compared categorical results and Ct values to those from standard NP swabs collected at the same time from the same patients. All testing was performed by RT-PCR on the Abbott SARS-CoV-2 RealTime EUA (limit of detection [LoD], 100 copies viral genomic RNA/mL transport medium). We found high concordance (Cohen's kappa $>0.8$ ) only for patients with viral loads above 1,000 copies $/ \mathrm{mL}$. Those with viral loads below 1,000 copies/mL, the majority in our cohort, exhibited low concordance (Cohen's kappa $=0.49$ ); most of these would have been missed by nasal testing alone. Previous reports of high concordance may have resulted from use of assays with higher $\operatorname{LoD}(\geq 1,000$ copies $/ \mathrm{mL})$. These findings counsel caution in use of nasal testing in healthcare settings and contact-tracing efforts, as opposed to screening of asymptomatic, low-prevalence, low-risk populations. Nasal testing is an adjunct, not a replacement, for NP.

\section{Introduction}

Controlling the COVID-19 pandemic will require a massive expansion of testing for SARS-CoV2 in several different clinical and epidemiological contexts. Until recently, nasopharyngeal (NP) swabs were the United States Centers for Disease Control and Prevention's (CDC) preferred specimen type, as these specimens were thought to provide the most robust detection of patient infection. However, there are conflicting reports as to which of several specimen types bear the highest viral load ${ }^{1-3}$, and ultimately the "preferred-specimen" specification was removed from interim CDC guidance on 29 April $2020^{4}$. Sensitivity is a complex issue, however, as detection in the upper airways (nasopharynx and oropharynx) is affected by multiple factors including 
medRxiv preprint doi: https://doi.org/10.1101/2020.06.12.20128736; this version posted June 14, 2020. The copyright holder for this preprint (which was not certified by peer review) is the author/funder, who has granted medRxiv a license to display the preprint in perpetuity.

It is made available under a CC-BY-NC-ND 4.0 International license .

duration of illness prior to testing ${ }^{5}$ as well as the limit of detection (LoD) of the RT-PCR assay used $^{6}$.

Availability of NP swabs and the resources to establish NP collection sites with specimen collection personnel have remained critical bottlenecks. To resolve these issues, healthcare systems have adopted multiple different strategies, including engaging industrial manufacturers to mass produce novel 3D-printed NP swabs ${ }^{7}$, as well as evaluating different specimen types and alternative sample-collection strategies ${ }^{8-16}$. Assessment of nasal swabs is a rapidly growing area of interest, specifically because this specimen type involves a less invasive procedure than NP swabs, as only the anterior-to-mid-turbinate area of the nasal passages is accessed. Accordingly, such samples can be self-collected by patients with a simple set of instructions, alleviating the need for highly trained medical personnel for specimen collection and reducing use of personal protective equipment (PPE) in short supply.

Many of the US Food and Drug Administration Emergency Use Authorization (FDA EUA) RTPCR assays have approval for use of nasal swabs as a specimen type, but how well nasal swabs perform compared to NP swabs remains unclear. To date, nasal-swab studies have shown conflicting results, with some researchers reporting similar test performance to NP swabs and others finding decreased sensitivity ${ }^{8,10,12-16}$. Reconciling these differences is challenging, as these studies employed different sampling materials, collection methods, and RT-PCR assays. To address these conflicting reports, here we describe results of a six-arm, 308-subject study comparing two different healthcare-worker nasal-swab collection procedures and three different transport conditions, including in viral transport media (VTM) and dry transport. We discuss our findings in the context of prior reports (including preprints), to more systematically assess nasalswab test performance and its potential role(s) in addressing diagnostic and epidemiologic needs in the COVID-19 pandemic.

\section{Materials and Methods}

Trial design. Participants were adults over 18 years of age tested for SARS-CoV-2 during the normal course of clinical care, based either on clinically suspected COVID-19 infection or followup after previous SARS-CoV-2-positive RT-PCR testing. Participants were asked to be swabbed twice, first with one of the nasal swabs under study (see below for swab-collection protocols) and then with a standard NP swab. To control for potential variability related to selfswabbing, sample collection was performed by trained nurses or respiratory-therapy staff 
medRxiv preprint doi: https://doi.org/10.1101/2020.06.12.20128736; this version posted June 14, 2020. The copyright holder for this preprint (which was not certified by peer review) is the author/funder, who has granted medRxiv a license to display the preprint in perpetuity.

It is made available under a CC-BY-NC-ND 4.0 International license .

("study staff") with training and oversight from the respiratory therapy department at Beth Israel Deaconess Medical Center (BIDMC) drive-through/walk-up (“drive-through") COVID-19 testing sites. Individuals with known thrombocytopenia $(<50,000$ platelets $/ \mu l)$ were excluded from the study to avoid risk of bleeding. This study was reviewed and approved by BIDMC's institutional review board (IRB protocol no. 2020P000451).

Transport conditions and swabs used. Standard nasal swabs were compared under three different specimen-transport conditions: (i) a guanidine thiocyanate (GITC) transport buffer, part of the Abbott multi-Collect Specimen Collection Kit, catalog no. 09K12-004; Abbott Laboratories, Abbott Park, IL), (ii) dry, with no buffer; and (iii) in modified CDC viral transport media (VTM) (Hank's balanced salt solution containing $2 \%$ heat inactivated FBS, $100 \mu \mathrm{g} / \mathrm{mL}$ gentamicin, $0.5 \mu \mathrm{g} / \mathrm{mL}$ fungizone, and $10 \mathrm{mg} / \mathrm{L}$ Phenol red, produced by the Beth Israel Deaconess Medical Center [BIDMC] Clinical Microbiology Laboratories ${ }^{17}$ ). The nasal swab used was the included Abbot swab for the GITC arm and the Hologic Aptima Multitest Swab otherwise (catalog no. AW-14334-001-003; Hologic Inc. Marlborough, MA). The NP swab used was the Copan BD ESwab collection and transport system swab (catalog no. 220532; Copan Diagnostics Inc., Murietta, CA).

PCR compatibility. Although all swabs are routinely used for PCR testing, as a double-check each swab type was assessed for PCR compatibility by overnight incubation in $3 \mathrm{~mL}$ of modified CDC VTM (allowing potential PCR inhibitors time to leech into media), spiking $1.5 \mathrm{~mL}$ of media with 200 copies/mL of control SARS-CoV-2 amplicon target (twice the LoD of our system), vortexed, and tested using the Abbott RealTime SARS-CoV-2 Assay on an Abbott m2000 RealTime System platform ${ }^{18}$, the assay and platform used for all testing in this report, following the same protocol used for clinical testing (see below). All swabs examined in this study passed this quality-control testing for lack of RT-PCR inhibition based on observation of Ct values within expected quality control limits ${ }^{17}$.

Swab collection protocols (Fig. 1). For Procedure 1, for each naris, the swab tip was inserted into the nostril, the patient was told to press a finger against the exterior of that naris, and the swab was rotated against this external pressure for 10 seconds (Fig. 1a); this procedure was repeated with the same swab on the other naris, and then the swab was placed into the collection tube for transport to the laboratory for testing. For Procedure 2, the swab was inserted into the naris until resistance was felt, and the swab was then rotated for 15 seconds without external pressure (Fig. 1b); this procedure was repeated with the same swab on the other naris, 
medRxiv preprint doi: https://doi.org/10.1101/2020.06.12.20128736; this version posted June 14, 2020. The copyright holder for this preprint (which was not certified by peer review) is the author/funder, who has granted medRxiv a license to display the preprint in perpetuity.

It is made available under a CC-BY-NC-ND 4.0 International license .

and the swab was then placed into the collection tube for transport ${ }^{15}$. The NP-swab sample was collected from a single naris by standard technique: insertion to appropriate depth, 10 rotations, removal, and placement into transport-media tube containing $\mathrm{VTM}^{4}$. To maximize collection of material from the nares, in all cases sampling using the nasal swab (both nares) was performed first, before the NP swab.

Sample processing and testing. Samples were sent to the BIDMC Clinical Microbiology Laboratories for testing. Dry swabs were eluted in $2 \mathrm{~mL}$ of Abbott $m$ Wash1 (100mM Tris with guanidinium isothiocyanate (GITC) and detergent). Swabs transported in GITC buffer were supplemented with $1 \mathrm{~mL}$ of Abbott $m$ Wash 1 solution to achieve minimum volume requirements for testing. Tests were performed with $1.5 \mathrm{~mL}$ of sample media using the Abbott RealTime SARS-CoV-2 assay for EUA for use with nasopharyngeal and nasal swabs ${ }^{18}$. This dual-target assay detects both the SARS-CoV-2 RdRp (RNA-dependent RNA polymerase) and N (nucleocapsid) genes with an in-lab verified LoD of 100 copies $/ \mathrm{mL}^{6,17}$.

Statistical analyses. RT-PCR results reported categorically as either positive or negative, and these were used for concordance testing by Cohen's kappa ${ }^{19}$.

For analyses based on cycle-threshold (Ct) values, for discordant samples (positive nasalswab/negative NP-swab result or vice versa), the negative result was assigned a Ct value of 37 , the total number of cycles run. Conversion to viral load was performed as described previously ${ }^{6}$.

We tested whether Ct values for a given set of nasal swabs differed from the $\mathrm{Ct}$ values for the paired NP swabs (the controls) using Wilcoxon's paired $t$-test. This tested the null hypothesis that values for controls and prototypes are drawn from the same underlying distribution; $p>0.05$ was interpreted as no difference. We used bootstrapping to test whether the $n$ results for a given arm exhibited appreciable differences from others, specifically by testing whether a given arm differed from random samples from $(i)$ results pooled across the three arms that used the same nasal-swab sampling procedure or (ii) all results. For each bootstrap test, we sampled $n$ data points at random from the larger pool to create a synthetic dataset, calculating Cohen's kappa on this synthetic dataset, and repeating this process for 100,000 synthetic datasets to create a distribution (histogram) of kappa values; this distribution constitutes a null model of the kappa one would expect to observe by chance in a sample of $n$ results, given the data in the larger pool. Using this distribution, we then calculated the probability of observing a kappa at least as high as the kappa actually observed for the $n$ results from a given arm, to test for 
medRxiv preprint doi: https://doi.org/10.1101/2020.06.12.20128736; this version posted June 14, 2020. The copyright holder for this preprint (which was not certified by peer review) is the author/funder, who has granted medRxiv a license to display the preprint in perpetuity.

It is made available under a CC-BY-NC-ND 4.0 International license .

consistency with expectation; inconsistency $(p<0.05$ or $p>0.95)$ would reject the null hypothesis that the study arm and the larger pool are statistically indistinguishable (as measured by kappa). For completeness, we performed the same bootstrap analysis to compare Procedure 1 results to all results and to compare Procedure 2 results to all results.

We used Python (v3.6-3.8) and its NumPy, SciPy, Matplotlib, Pandas, and ct2vl libraries for the above analyses and related visualizations.

Literature review. We searched Pubmed and the preprint servers bioRxiv and medRxiv through June 1, 2020 for all literature on nasal-swab sampling for SARS-CoV-2 and extracted sample sizes, collection methods, RT-PCR assay information, and $2 \times 2$ contingency table data comparing nasal swabs to NP swabs wherever available.

\section{Results}

Table 1 shows the numbers of patients tested in each of the six arms of our nasal- vs. NP-swab study. Visual inspection of plots of the Ct values of the nasal swab vs. NP-swab controls suggested worse performance for nasal swabs across all six arms, with no obvious differences between the two swab procedures or among the dry-swab, VTM, or GITC collection methods (Fig. 2). Statistical testing confirmed that results for each arm were indistinguishable from the overall results, supporting the functional equivalence of all swab/transport-condition combinations (Table 2). For concordant positives, comparison of $\mathrm{Ct}$ values between nasal and NP swabs showed higher Cts for nasal swabs than for NP swabs, suggesting slightly but consistently lower yield from the nasal swabs (Wilcoxon $p=9 \times 10^{-11}$ ). Consistent with this conclusion, there was a marked increase in false negatives for NP-swabs with higher Ct values (lower viral loads), resulting in low concordance overall (Cohen's kappa=0.49) (Fig. 2).

Our overall finding of low concordance was in contrast to some previous reports, which have found nasal-swab collection to exhibit excellent sensitivity as well as Ct-value concordance ${ }^{13,15}$, but was consistent with others ${ }^{10,14}$, including, for example, one recent study at a New York, USA, hospital that also noted lower nasal-swab concordance for higher Ct values ${ }^{16}$. Close review of these previous reports revealed that they differed in the type of specimen and/or result they used as a reference (e.g. any test-sample positive versus using NP swabs as the gold standard) and in the parameters they used in order to describe test performance (e.g. positive percent agreement versus sensitivity). To control for at least the latter, we extracted $2 \times 2$ 
medRxiv preprint doi: https://doi.org/10.1101/2020.06.12.20128736; this version posted June 14, 2020. The copyright holder for this preprint (which was not certified by peer review) is the author/funder, who has granted medRxiv a license to display the preprint in perpetuity.

It is made available under a CC-BY-NC-ND 4.0 International license .

contingency-table data from these reports to facilitate comparison to each other and to our own results (Table 3). Notably, many of these studies used a modified version of the CDC assay that did not report a LoD. Furthermore, of the studies that report the Ct values of their results, no viral-load conversion was provided, which is important since different RT-PCR assays and platforms have unique conversions between $\mathrm{Ct}$ value and viral load. Therefore, we were unable to systematically compare nasal-swab performance at low viral loads in these reports. These differences left open the possibility that inconsistent comparative performance of nasal-swab sampling might be explained largely by differences assay LoD, and possibly also by patient viral load. (We note that while the nasal-swab sampling protocols and transport media conditions varied between studies, our results suggest these differences are unlikely to affect detection).

We therefore revisited the trend we observed of a rise in nasal-swab-negative discordant results (false negatives) with higher Ct value. Recently we demonstrated that $\mathrm{Ct}$ values for the SARSCoV-2 RT-PCR assay and platform used in the present study are reliable quantitative measures of viral load, and introduced a conversion from Ct value to viral load ${ }^{6}$. Building on those findings, here we asked what the concordance would have been, for our nasal-vs.-NP data, had the LoD of our assay been higher than its actual 100 copies $/ \mathrm{mL}$. Specifically, we re-calculated kappa for different LoD cutoffs, and found that kappa rose steeply from $\sim 0.5$ (low concordance) to 0.8-0.9 (excellent concordance) as the LoD cutoff was increased from 100 copies/mL through 1,000 copies/mL and beyond (Fig. 3). This finding strongly supports the view that nasal swabs miss many if not most patients with low viral load (below $\sim 1,000$ copies $/ \mathrm{mL}$ ), but is reliable for patients with medium or high viral loads, potentially resolving disagreements among previous reports.

\section{Discussion}

It is widely acknowledged that resolving the damage that the COVID-19 pandemic has wrought to health, the economy, and society will require distributing and scaling up testing to unprecedented levels. For this reason, there is great and widespread interest in developing alternatives to NP-swab sampling for COVID-19 diagnosis. Governments and medical institutions alike have expressed interest in adopting nasal swabs as an alternative, as the selfadministration of these swabs would allow vastly increased testing capacity, save PPE, and ease the burden on healthcare workers. Independently, the ability to transport swabs to testing locations without need of transport media such as VTM would further streamline testing 
medRxiv preprint doi: https://doi.org/10.1101/2020.06.12.20128736; this version posted June 14, 2020. The copyright holder for this preprint (which was not certified by peer review) is the author/funder, who has granted medRxiv a license to display the preprint in perpetuity.

It is made available under a CC-BY-NC-ND 4.0 International license .

206

207

208

209

210

211

212

213

214

215

216

217

218

219

220

221

222

223

224

225

226

227

228

229

230

231

232

233

234

235

236 processes. Reflecting this interest in nasal swabs, the US CDC has removed the "preference" specification for NP swabs from their interim guidance and note that nasal swabs are an acceptable alternative specimen as of 29 April $2020^{4}$. However, confidence in population-scale testing strategies based on nasal swabs is complicated by conflicting reports as to how well they perform relative NP swabs, the antecedent gold standard, as we have described.

Our results strongly suggest that concordance between nasal and NP swabs depends on the LoD of the PCR assay used to measure positivity, with high concordance for medium-to-high viral loads and low concordance for low viral loads, which may lie below the LoDs of various assays currently in widespread use (Fig. 3$)^{6}$. We find that nasal swab samples reliably detect patients with viral loads $\geq 1,000$ copies/mL but miss many patients who have lower viral loads, the majority in our study ${ }^{6}$. A complete biological explanation will require further study; however, one possibility is that in cases of high viral load, replicating virus may be more likely to spread to respiratory epithelium bordering and/or in the deeper portions of the anterior nares, where it can be recovered by nasal swab.

our findings may reconcile disagreements in prior reports, which have compared nasal swab performance only as a function of $\mathrm{Ct}$ values which are not comparable from study to study, not viral load, as we have done here,. We hypothesize that the outpatient/urgent care testing sites in these studies may have selected for patients early in the course of disease, when viral load is high $^{13,15}$. For example, one study ${ }^{13}$ that showed high concordance used an assay with a negative Ct cutoff of 40 , and only a handful of patient samples had Ct values above 35. Although again the viral loads were not reported, the discrepancy between cutoff and Ct values suggested preferential sampling of patients with only high viral loads. (Note that a Ct value of 35 can correspond to different viral loads in different assays and the LoD of this assay was 4,167 copies/mL, over 40 times the cutoff in the assay we used.) Notably, the patient population in the present study consisted of both first-time and individuals with repeat testing for test of cure. Many of the latter have been observed to exhibit low-level viral load for multiple weeks in the absence of severe symptoms and enrichment of these patients may impact the overall performance of NP and nasal swabs in individual studies. In other studies, such differences may be more or less obscured depending on the limit of detection of the assay in use which may straddle the 1,000 copies/mL threshold we found for nasal swabs to consistently detect infection. 
medRxiv preprint doi: https://doi.org/10.1101/2020.06.12.20128736; this version posted June 14, 2020. The copyright holder for this preprint (which was not certified by peer review) is the author/funder, who has granted medRxiv a license to display the preprint in perpetuity.

It is made available under a CC-BY-NC-ND 4.0 International license .

Interestingly, we found no difference among transport media conditions and between sampling protocols, suggesting that lower sensitivity of nasal swab sampling is an overall limitation of the anatomical location of nasal swabs and that the protocols and media conditions we tested are interchangeable. Thus, for patients above a critical threshold of 1,000 copies/mL (Fig. 2), nasal swabs collected in VTM, GITC transport medium, and as dry swabs are all likely to perform equally well in the population, providing multiple potential options for specimen acquisition.

Our results suggest several settings in which nasal swabs may and may not best be used. Peak infectiousness is likely to occur near or shortly before symptom onset ${ }^{20,21}$ and nasopharyngeal viral load is often undetectable a week after symptom onset ${ }^{2}$. Lower-sensitivity testing would therefore likely miss patients with early developing presymptomatic infections and patients presenting multiple days after symptom onset. Notably, for those presenting later to care, a false-negative diagnosis could bear significant clinical implications in not only erroneously reassuring the patient and clinical team, but also excluding them from potentially useful and rationed therapies such as remdesivir ${ }^{22}$ or others. Importantly, based on viral load distribution in first-time tested individuals at our institution, $20 \%$ of newly presenting SARS-CoV-2 positive individuals would be missed if sampled solely using nasal swabs ${ }^{6}$, highlighting the potential magnitude of this problem.

Nevertheless, nasal swabs provide considerable advantage in terms of ease of collection and potential self-collection. Based on our results, they would serve best in high-test-volume, point prevalence screens in healthy populations, for example, in businesses and universities, where identification of highly infectious individuals will be a prelude to targeted testing with the most sensitive techniques possible to quell outbreaks and forestall local spread. Conversely, nasal swabs should not be used for screening symptomatic and especially hospitalized patients, where the more sensitive and resource intensive nasopharyngeal sampling would be justified, and help direct care and most appropriate use of infection control resources. In summary, whilst nasal swabs are a welcome addition to the armamentarium of tools needed to combat COVID19 , we should be well aware of possible limitations in diagnostic sensitivity and use this resource judiciously.

\section{Acknowledgements}

The authors would like to acknowledge Dr. Yuan-Po Tu for graciously sharing his nasal swab protocol and Susan E. Devito, Kelly Gibbs, Angela E. Martignetti, Nancy R. Sheridan, Carl A. 
268 Santiago, Erin Martin, Erin K. Martin, Janet Mulvey, Mallory Flynn, Shannon Healy, Lauren

269 Kennedy, Jill Lococo, Jose A. Abrego, Tracy Flynn, Jean M. Pietrantonio, Kelina Orlando, Carol

270 Daugherty, (Carl) Adrian Santiago, Ann Marie Zampitella, Scott Hamelin, Maria Ortega, Frantzia

271 Clermont, April Gagnon, Elvia Pires Barbosa Fernandes, Brenda Pinto, Brittany

272 Williamson, Mairie Taline Dorcely, Sheila Moriarty, Kathy Corley, and Paula Stering for their

273 assistance in conducting this study.

274 Abbott multi-Collect Specimen Collection Kits were a generous gift of Abbott Laboratories.

275 K.E.Z. was supported by a National Institute of Allergy and Infectious Diseases training grant

276 (T32AI007061).

277 This work was conducted with support from The Harvard Clinical and Translational Science

278 Center (National Center for Advancing Translational Sciences, National Institutes of Health

279 Award UL 1TR002541) and financial contributions from Harvard University and its affiliated

280 academic healthcare centers. The content is solely the responsibility of the authors and does

281 not necessarily represent the official views of Harvard Catalyst, Harvard University and its

282 affiliated academic healthcare centers, or the National Institutes of Health. 
medRxiv preprint doi: https://doi.org/10.1101/2020.06.12.20128736; this version posted June 14, 2020. The copyright holder for this preprint (which was not certified by peer review) is the author/funder, who has granted medRxiv a license to display the preprint in perpetuity.

It is made available under a CC-BY-NC-ND 4.0 International license .

Tables and Figures

Table 1: Number of specimens by study arm

\begin{tabular}{c|c|c|c}
$\begin{array}{c}\text { Collection } \\
\text { method }\end{array}$ & GITC & Dry & VTM \\
\hline Procedure 1 & $47(1)$ & $36(2)$ & $39(3)$ \\
\hline Procedure 2 & $65(4)$ & $61(5)$ & $60(6)$
\end{tabular}

285 Procedures 1 and 2 as in Methods and Fig. 1. Numbers in parentheses indicate study arms. 
medRxiv preprint doi: https://doi.org/10.1101/2020.06.12.20128736; this version posted June 14, 2020. The copyright holder for this preprint (which was not certified by peer review) is the author/funder, who has granted medRxiv a license to display the preprint in perpetuity.

\begin{tabular}{lc} 
Comparison & p-value \\
\hline Arm (1) vs. all Procedure 1 & 0.11 \\
Arm (2) vs. all Procedure 1 & 0.85 \\
Arm (3) vs. all Procedure 1 & 0.62 \\
Arm (4) vs. all Procedure 2 & 0.78 \\
Arm (5) vs. all Procedure 2 & 0.30 \\
Arm (6) vs. all Procedure 2 & 0.53 \\
\hline Arm (1) vs. total & 0.27 \\
Arm (2) vs. total & 0.82 \\
Arm (3) vs. total & 0.62 \\
Arm (4) vs. total & 0.71 \\
Arm (5) vs. total & 0.23 \\
Arm (6) vs. total & 0.44 \\
\hline Procedure 1 vs. total & 0.66 \\
Procedure 2 vs. total & 0.29
\end{tabular}

287 Listed are $p$-value for bootstrap comparison of linear-regression fits of Ct values of nasal swab 288 vs. NP swab for observed samples for arms 1-6 from Table 1 vs. 10,000 random samples of 289 either Procedure 1 (top three rows), Procedure 2 (next three rows), total (next six rows). Bottom 290 two rows are bootstrap comparisons of all Procedure 1 (i.e., arms 1-3) to total and Procedure 2 291 (arms 4-6) to total. All comparisons show $p>0.05$, interpreted as no significant differences 292 among arms and procedures. 
萬

U્山

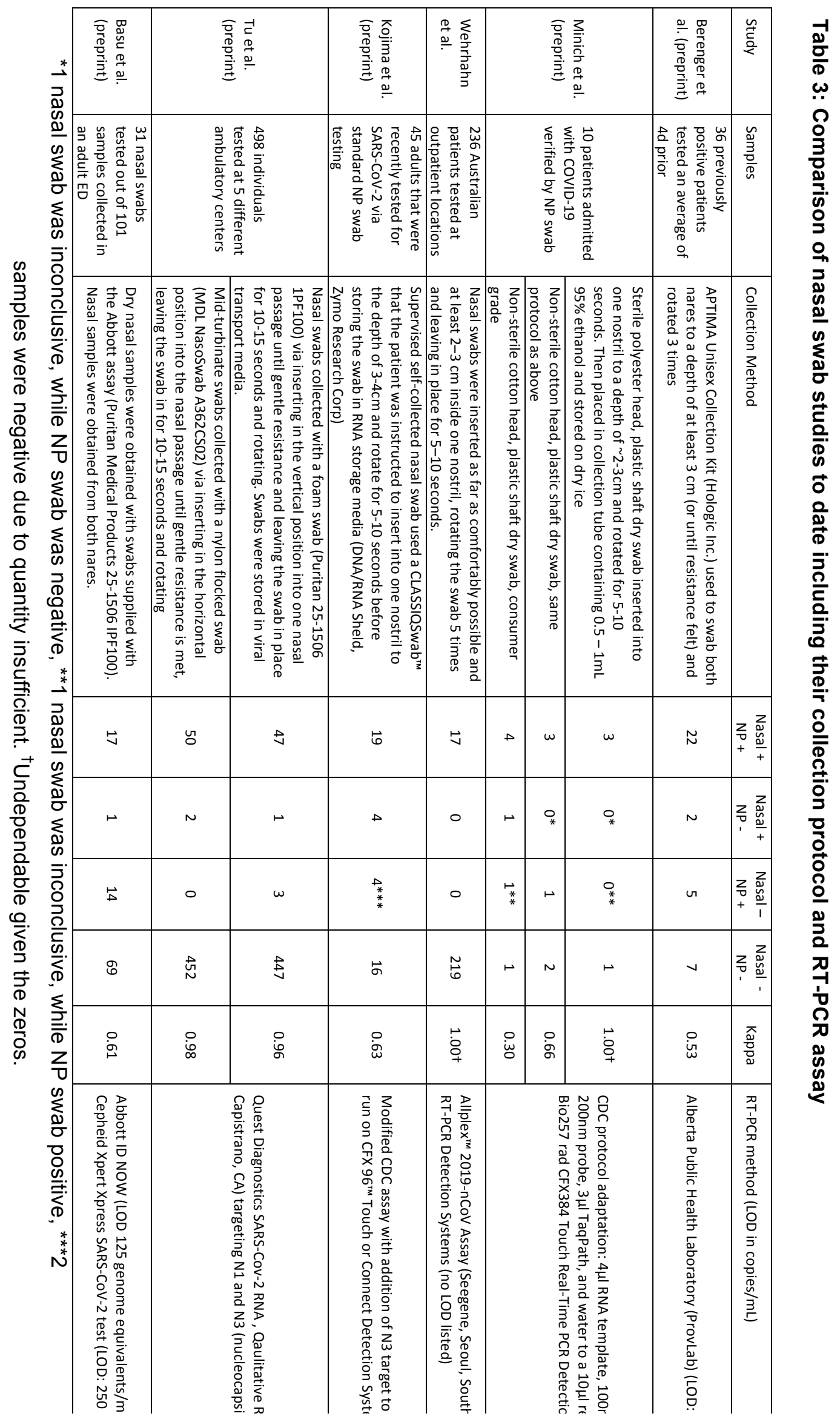


medRxiv preprint doi: https://doi.org/10.1101/2020.06.12.20128736; this version posted June 14, 2020. The copyright holder for this preprint (which was not certified by peer review) is the author/funder, who has granted medRxiv a license to display the preprint in perpetuity. It is made available under a CC-BY-NC-ND 4.0 International license .

జ్̊
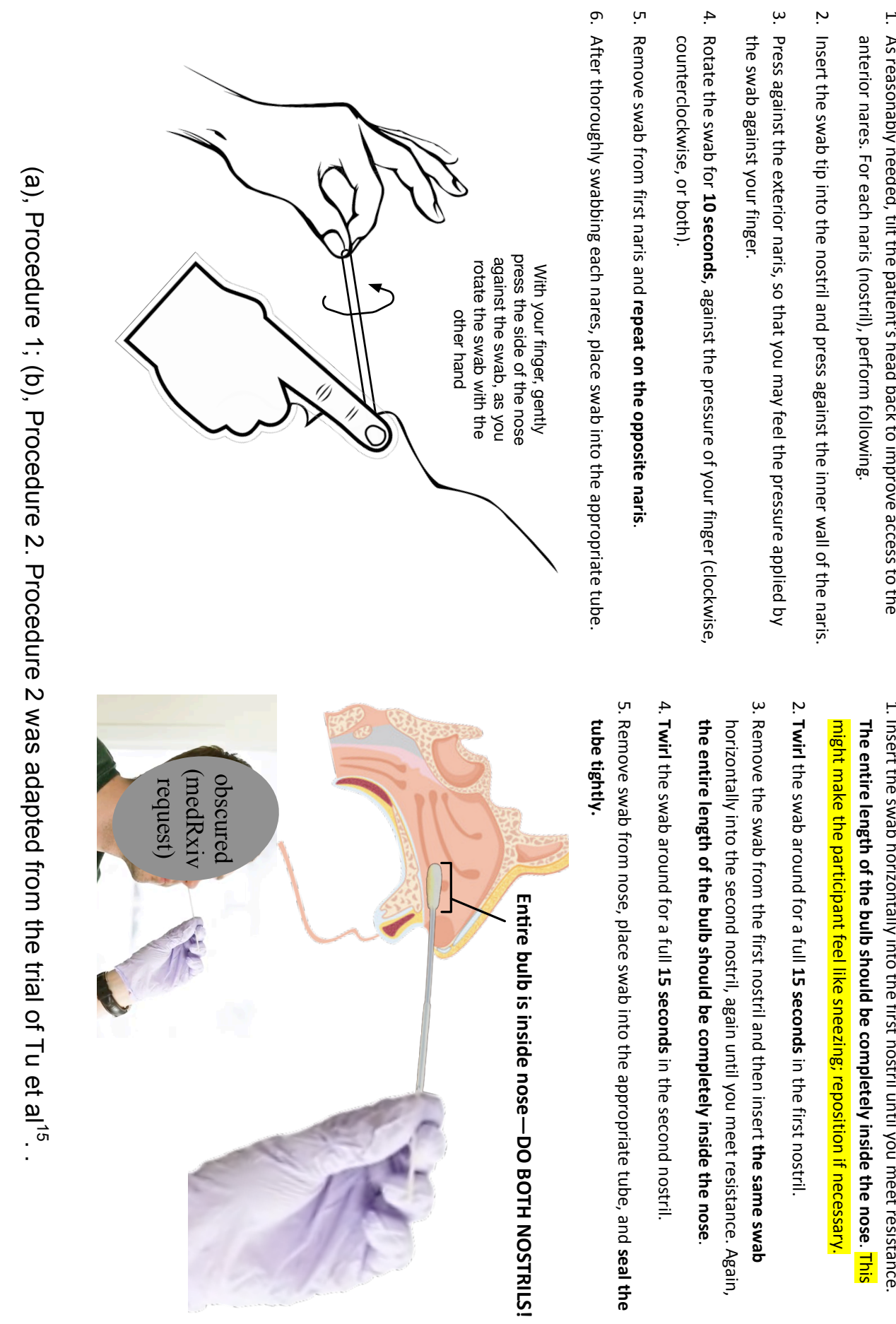

a)
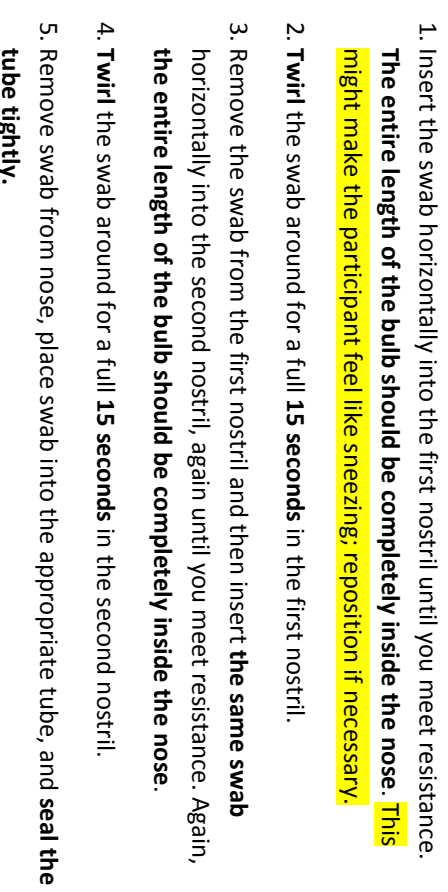

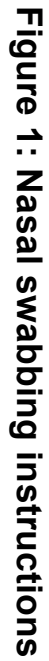




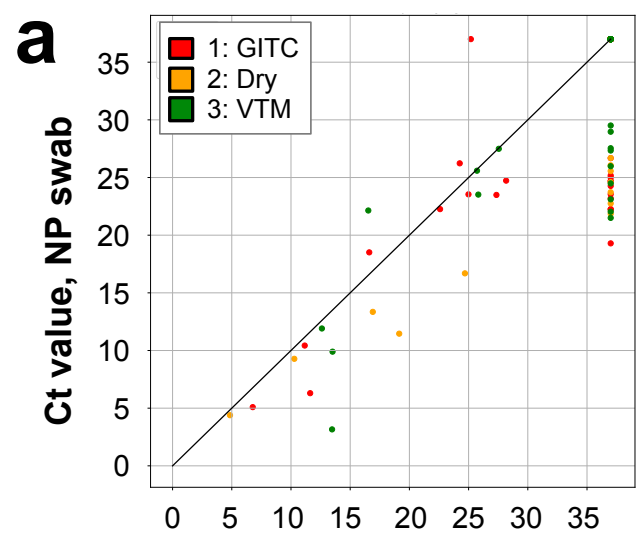

$$
\begin{aligned}
& \begin{array}{ccc}
\text { GITC } & \text { Dry } & \text { VTM } \\
\kappa=0.44 & \kappa=0.49 & \kappa=0.26
\end{array}
\end{aligned}
$$

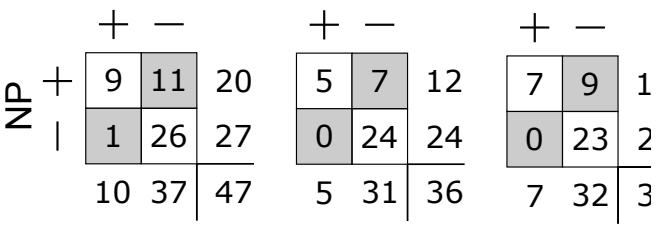
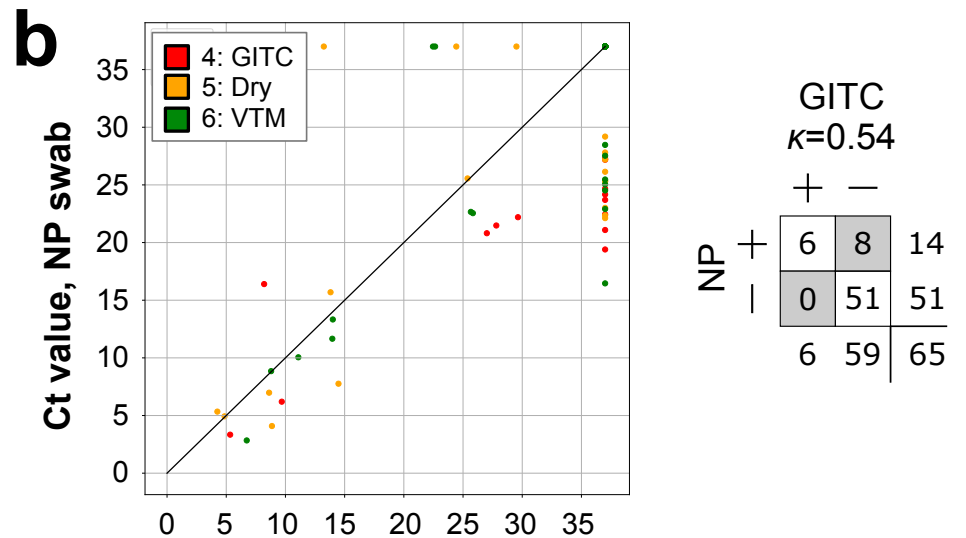

VTM

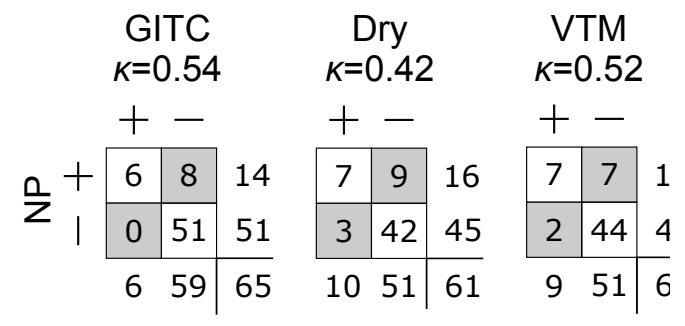

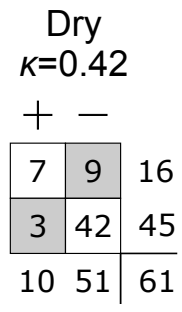

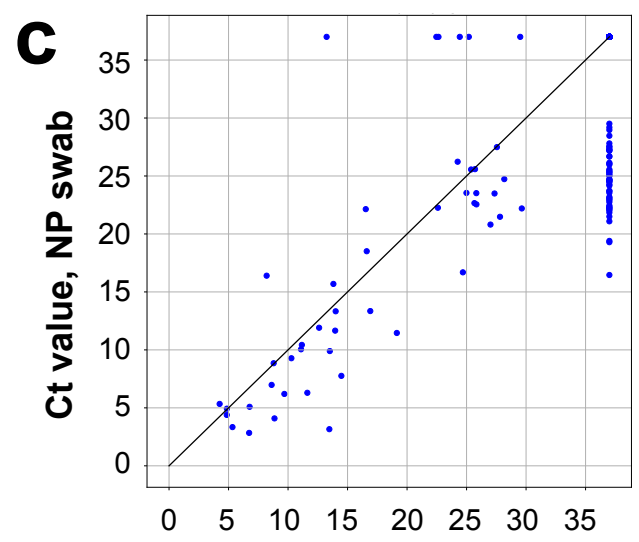

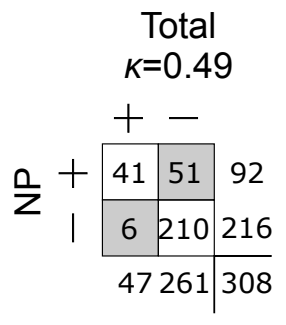

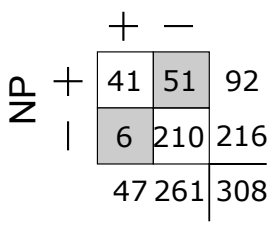

Ct value, nasal swab

301 (a) Procedure 1; (b) Procedure 2; (c) total. Negatives are plotted with a Ct value of 37

302 (maximum cycle no.): vertically stacked data points at the far right of the plots (x-axis valu

30337 ) are false negatives, while data points at the top of the plots ( $y$-axis value $=37$ ) are fal: positives. Legend: study-arm numbers are the same as in Tables 1 and 2. $K$, Cohen's kar 
medRxiv preprint doi: https://doi.org/10.1101/2020.06.12.20128736; this version posted June 14, 2020. The copyright holder for this preprint (which was not certified by peer review) is the author/funder, who has granted medRxiv a license to display the preprint in perpetuity.

It is made available under a CC-BY-NC-ND 4.0 International license .

Figure 3: Low vs. high concordance depends on low vs. high assay sensitivity

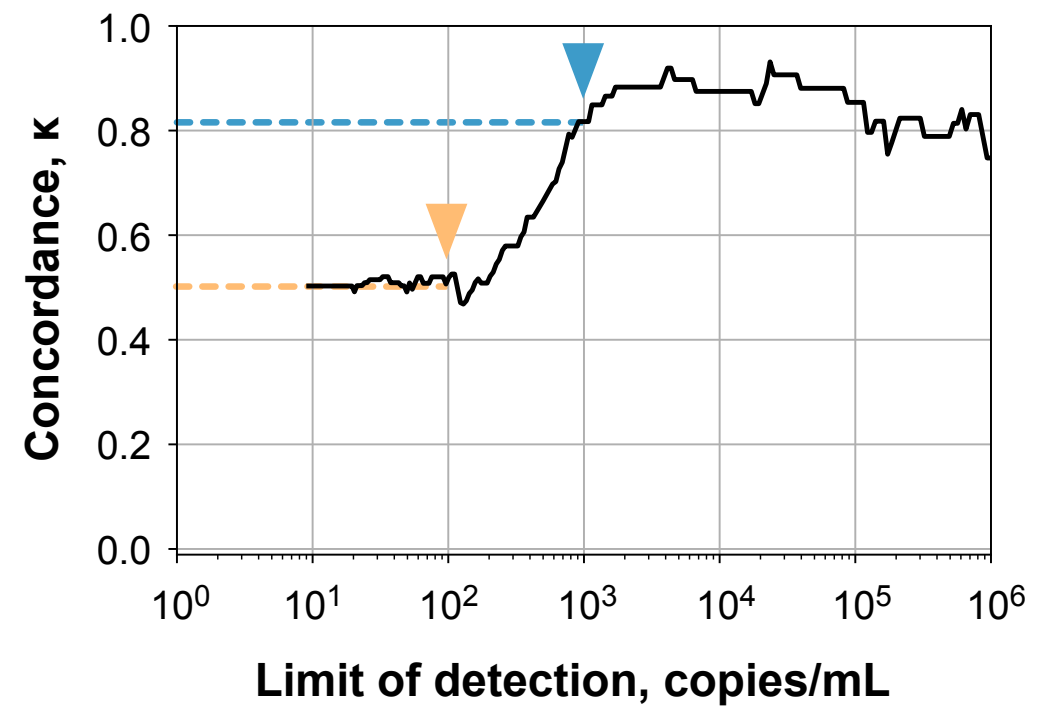

307 Concordance (measured by Cohen's kappa) plotted against assay LoD. With LoD of 100

308 copies/mL (yellow arrowhead) the Abbott assay detects false negatives in nasal-swab samples,

309 resulting in low concordance (0.49; yellow dotted line). An assay with LoD of 1,000 copies/mL

310 (blue arrowhead) would have missed these false negatives, which would have yielded a high

311 observed concordance (0.82; blue dotted line). 
medRxiv preprint doi: https://doi.org/10.1101/2020.06.12.20128736; this version posted June 14, 2020. The copyright holder for this preprint (which was not certified by peer review) is the author/funder, who has granted medRxiv a license to display the preprint in perpetuity.

It is made available under a CC-BY-NC-ND 4.0 International license .

\section{References}

313

314

315

316

1 Yang $Y$, Yang M, Shen C, et al. Evaluating the accuracy of different respiratory specimens in the laboratory diagnosis and monitoring the viral shedding of 2019-nCoV infections. medRxiv 2020; : 2020.02.11.20021493.

2 Wölfel R, Corman VM, Guggemos W, et al. Virological assessment of hospitalized patients with COVID-2019. Nature 2020; 581: 465-9.

3 Saliva is more sensitive for SARS-CoV-2 detection in COVID-19 patients than nasopharyngeal swabs | medRxiv. https://www.medrxiv.org/content/10.1101/2020.04.16.20067835v1 (accessed June 9, 2020).

4 CDC. Information for Laboratories about Coronavirus (COVID-19). Cent. Dis. Control Prev. 2020; published online Feb 11. https://www.cdc.gov/coronavirus/2019-ncov/lab/guidelinesclinical-specimens.html (accessed June 10, 2020).

5 Huang J-T, Ran R-X, Lv Z-H, et al. Chronological Changes of Viral Shedding in Adult Inpatients with COVID-19 in Wuhan, China. Clin Infect Dis DOI:10.1093/cid/ciaa631.

6 Arnaout R, Lee RA, Lee GR, et al. SARS-CoV2 Testing: The Limit of Detection Matters. bioRxiv 2020; : 2020.06.02.131144.

7 Callahan CJ, Lee R, Zulauf KE, et al. Open Development and Clinical Validation Of Multiple 3D-Printed Nasopharyngeal Collection Swabs: Rapid Resolution of a Critical COVID-19 Testing Bottleneck. J Clin Microbiol 2020; : JCM.00876-20, jcm;JCM.00876-20v1.

8 LeBlanc JJ, Heinstein C, MacDonald J, Pettipas J, Hatchette TF, Patriquin G. A combined oropharyngeal/nares swab is a suitable alternative to nasopharyngeal swabs for the detection of SARS-CoV-2. J Clin Virol 2020; 128: 104442.

9 Rhoads DD, Cherian SS, Roman K, Stempak LM, Schmotzer CL, Sadri N. Comparison of Abbott ID Now, Diasorin Simplexa, and CDC FDA EUA methods for the detection of SARSCoV-2 from nasopharyngeal and nasal swabs from individuals diagnosed with COVID-19. $J$ Clin Microbiol 2020; : JCM.00760-20, jcm;JCM.00760-20v1.

10 Minich JJ, Ali F, Marotz C, et al. Feasibility of SARS-CoV-2 virus detection from consumergrade cotton swabs. medRxiv 2020; : 2020.05.12.20073577. 
medRxiv preprint doi: https://doi.org/10.1101/2020.06.12.20128736; this version posted June 14, 2020. The copyright holder for this preprint (which was not certified by peer review) is the author/funder, who has granted medRxiv a license to display the preprint in perpetuity.

It is made available under a CC-BY-NC-ND 4.0 International license .

11 McCormick-Baw C, Morgan K, Gaffney D, et al. Saliva as an Alternate Specimen Source for Detection of SARS-CoV-2 in Symptomatic Patients Using Cepheid Xpert Xpress SARS-CoV2. J Clin Microbiol 2020; : JCM.01109-20, jcm;JCM.01109-20v1.

12 Kojima N, Turner F, Slepnev V, et al. Self-Collected Oral Fluid and Nasal Swabs Demonstrate Comparable Sensitivity to Clinician Collected Nasopharyngeal Swabs for Covid19 Detection. medRxiv 2020; : 2020.04.11.20062372.

13Wehrhahn MC, Robson J, Brown S, et al. Self-collection: An appropriate alternative during the SARS-CoV-2 pandemic. J Clin Virol 2020; 128: 104417.

14Berenger BM, Fonseca K, Schneider AR, Hu J, Zelyas N. Sensitivity of Nasopharyngeal, Nasal and Throat Swab for the Detection of SARS-CoV-2. medRxiv 2020; : 2020.05.05.20084889.

15Tu Y-P, Jennings R, Hart B, et al. Swabs Collected by Patients or Health Care Workers for SARS-CoV-2 Testing. N Engl J Med 2020; 0. DOI:10.1056/NEJMc2016321.

16Basu A, Zinger T, Inglima K, et al. Performance of the rapid Nucleic Acid Amplification by Abbott ID NOW COVID-19 in nasopharyngeal swabs transported in viral media and dry nasal swabs, in a New York City academic institution. bioRxiv 2020; : 2020.05.11.089896.

17 Smith KP, Cheng A, Chopelas A, et al. Large-scale, in-house production of viral transport media to support SARS-CoV-2 PCR testing in a multi-hospital healthcare network during the COVID-19 pandemic. J Clin Microbiol 2020; published online May 13.

DOI:10.1128/JCM.00913-20.

18Anonymous. Abbott RealTime SARS-CoV-2 Emergency Use Authorization Package Insert. REF 09N77-095, 51-608445/R1. https://www.fda.gov/media/136258/download (accessed June 8, 2020).

19 McHugh ML. Interrater reliability: the kappa statistic. Biochem Medica 2012; 22: 276-82.

$20 \mathrm{He}$ X, Lau EHY, Wu P, et al. Temporal dynamics in viral shedding and transmissibility of COVID-19. Nat Med 2020; 26: 672-5.

21 Arons MM, Hatfield KM, Reddy SC, et al. Presymptomatic SARS-CoV-2 Infections and Transmission in a Skilled Nursing Facility. N Engl J Med 2020; 382: 2081-90. 
medRxiv preprint doi: https://doi.org/10.1101/2020.06.12.20128736; this version posted June 14, 2020. The copyright holder for this preprint (which was not certified by peer review) is the author/funder, who has granted medRxiv a license to display the preprint in perpetuity. It is made available under a CC-BY-NC-ND 4.0 International license.

36822 Wang Y, Zhang D, Du G, et al. Remdesivir in adults with severe COVID-19: a randomised, 369 double-blind, placebo-controlled, multicentre trial. The Lancet 2020; 395: 1569-78.

370 